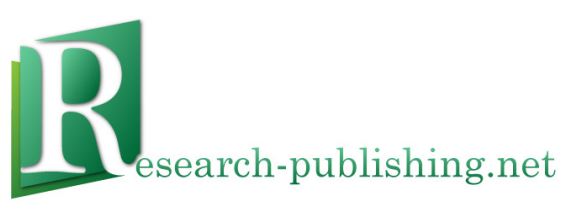

Published by Research-publishing.net

Dublin, Ireland; Voillans, France

info@research-publishing.net

(C) 2013 by Research-publishing.net

Research-publishing.net is a not-for-profit association

20 Years of EUROCALL: Learning from the Past, Looking to the Future.

2013 EUROCALL Conference, Évora, Portugal, Proceedings

Edited by Linda Bradley and Sylvie Thouësny

The moral right of the authors has been asserted

All articles in this book are licensed under a Creative Commons Attribution-Noncommercial-No Derivative Works 3.0 Unported License. You are free to share, copy, distribute and transmit the work under the following conditions:

- Attribution: You must attribute the work in the manner specified by the publisher.

- Noncommercial: You may not use this work for commercial purposes.

- No Derivative Works: You may not alter, transform, or build upon this work.

Research-publishing.net has no responsibility for the persistence or accuracy of URLs for external or thirdparty Internet websites referred to in this publication, and does not guarantee that any content on such websites is, or will remain, accurate or appropriate. Moreover, Research-publishing.net does not take any responsibility for the content of the pages written by the authors of this book. The authors have recognised that the work described was not published before (except in the form of an abstract or as part of a published lecture, or thesis), or that it is not under consideration for publication elsewhere. While the advice and information in this book are believed to be true and accurate on the date of its going to press, neither the authors, the editors, nor the publisher can accept any legal responsibility for any errors or omissions that may be made. The publisher makes no warranty, expressed or implied, with respect to the material contained herein.

Trademark notice: product or corporate names may be trademarks or registered trademarks, and are used only for identification and explanation without intent to infringe.

Copyrighted material: every effort has been made by the editors to trace copyright holders and to obtain their permission for the use of copyrighted material in this book. In the event of errors or omissions, please notify the publisher of any corrections that will need to be incorporated in future editions of this book.

Typeset by Research-publishing.net

Cover design: (C) Raphaël Savina (raphael@savina.net)

Photos: (c) Fany Savina (fany.savina@gmail.com)

Fonts used are licensed under a SIL Open Font License

ISBN13: 978-1-908416-12-4 (Paperback, Print on Demand, Lulu.com)

ISBN13: 978-1-908416-13-1 (Ebook, PDF file, Open Access, Research-publishing.net)

ISBN13: 978-1-908416-14-8 (Ebook, Kindle Edition, Amazon Media EU S.à r.1.)

ISBN13: 978-1-908416-15-5 (Ebook, ePUB file, Open Access, Research-publishing.net)

Legal deposit, Ireland: The National Library of Ireland, The Library of Trinity College, The Library of the University of Limerick, The Library of Dublin City University, The Library of NUI Cork, The Library of NUI Maynooth, The Library of University College Dublin, The Library of NUI Galway.

Legal deposit, United Kingdom: The British Library.

British Library Cataloguing-in-Publication Data.

A cataloguing record for this book is available from the British Library.

Legal deposit, France: Bibliothèque Nationale de France - Dépôt légal: novembre 2013. 

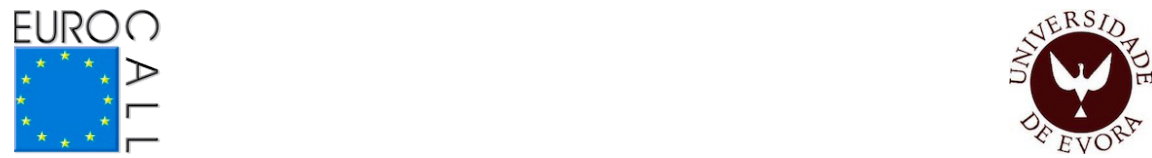

\title{
Categorization of Digital Games in English Language Learning Studies: Introducing the SSI Model
}

\author{
Pia Sundqvist ${ }^{1}$
}

\begin{abstract}
The main aim of the present paper is to introduce a model for digital game categorization suitable for use in English language learning studies: the Scale of Social Interaction (SSI) Model (original idea published as Sundqvist, 2013). The SSI Model proposes a classification of commercial off-the-shelf (COTS) digital games into three categories: singleplayer (the smallest scale), multiplayer, and massively multiplayer online games (MMOs, the largest scale). The potential for naturalistic learning (Benson, 2011) of English is hypothesized to be greater the larger the scale of in-game social interaction. A secondary aim is to present preliminary findings regarding the validation of the SSI Model based on data collected from Swedish learners (9th grade) in an ongoing 3-year study about the relation between out-of-school digital gameplay and vocabulary acquisition. The results reveal, for example, that it is more common that learners who play games frequently play multiplayer games and/or MMOs than singleplayer games. Moreover, the results provide partial evidence of the validity of the SSI Model in that the learners who are categorized as playing multiplayer games and MMOs score higher on two vocabulary tests than the learners categorized as playing singleplayer games.
\end{abstract}

Keywords: CALL, computer games, digital games, COTS, MMO, vocabulary acquisition, naturalistic learning, ESL, EFL, social interaction, self-assessment.

\section{Introduction}

Over the years, a number of ways of categorizing digital games have been suggested. Game categorization is necessary for researchers who are interested

1. Karlstad University, Faculty of Arts and Social Sciences, Karlstad, Sweden; pia.sundqvist@kau.se

How to cite this article: Sundqvist, P. (2013). Categorization of Digital Games in English Language Learning Studies: Introducing the SSI Model. In L. Bradley \& S. Thouësny (Eds.), 20 Years of EUROCALL: Learning from the Past Looking to the Future. Proceedings of the 2013 EUROCALL Conference, Evvora, Portugal (pp. 231-237). Dublin/Voillans: (C) Research-publishing.net. 
in exploring the relations between digital gameplay and language learning. However, within the gaming industry, there is little consensus about how to classify games (Apperley, 2006; Dickey, 2006; Harteveld \& Bekebrede, 2011).

Likewise, I have found it difficult to find an approach for categorization within the broad field of second language acquisition, even though some models have been proposed (e.g. deHaan, 2005; Greenberg, Sherry, Lachlan, Lucas, \& Holmstrom, 2010; Kinzie \& Joseph, 2008). Kinzie and Joseph (2008), for instance, bring forward six activity modes (active, explorative, problem-solving, strategic, social, and creative) to describe digital gameplay. In all these, a game such as World of Warcraft ends up being classified into several modes/genres. This makes analytical procedures complex, especially if a quantitative method is adopted.

In the SSI Model, a game taxonomy that springs from one single mode/axis is used, namely the scale of the social interaction in the game, which is directly linked to the number of players simultaneously involved in playing the game (for a detailed description, see Sundqvist, 2013). The present paper aims to introduce the SSI Model to CALL researchers and to present some preliminary findings regarding its validation.

\section{Method}

\subsection{Participants and materials}

This article is based on data collected during the first year of an ongoing 3-year study (2011-2014) about the relation between extramural English (Sundqvist, $2009,2011)$ and vocabulary acquisition among Swedish 15- and 16-year-olds $(N=280)$. More specifically, the focus is on one extramural/out-of-school activity: digital gameplay.

Several sets of data are collected each school year, including a questionnaire, two vocabulary tests (shortened versions of the Productive Levels Test and the Vocabulary Levels Test, Laufer \& Nation, 1999; Nation, 2001), and the school leaving certificate. The questionnaire provides information about the participants' first language, computer habits in English (e.g. digital gameplay activity: time played and types of games played), speaking anxiety, beliefs about language learning, and self-assessed English ability. The Productive Levels Test (PLT) is taken in the fall semester and the Vocabulary Levels Test (VLT) in the spring. For the present paper, questionnaire data about digital gaming habits are used along with data from the vocabulary tests. 


\subsection{Design}

The sample was divided into five groups depending on their responses to a questionnaire item that asked about how frequently the learners played digital games and also about example(s) of game title(s). Brief group descriptions are provided in Table 1. In Table 2, the distribution of learners in groups 2-5 are cross-tabulated with the frequency of gameplay $\left(\chi^{2}=344.538, d f=12, p=.000\right.$, $\varphi_{\mathrm{c}}=.650$; see Analytic procedure). For validation of the SSI Model, the non-gamers in group 1 are irrelevant and, therefore, excluded.

Table 1. Five groups based on frequency of gameplay and provision of game title(s)

\begin{tabular}{|rlcc|}
\hline \multicolumn{1}{|c}{ Group } & N & $\mathbf{\%}$ \\
\hline 1. & Non-gamers & 108 & 38.6 \\
\hline 2. & Gamers who do not provide any game title(s) & 22 & 7.9 \\
\hline 3. & Gamers who provide only singleplayer game title(s) & 31 & 11.1 \\
\hline 4. & $\begin{array}{l}\text { Gamers who provide multiplayer game title(s) and possibly also singleplayer game } \\
\text { title(s), but no massively multiplayer game title(s) }\end{array}$ & 82 & 29.3 \\
5. & $\begin{array}{l}\text { Gamers who provide massively multiplayer game title(s) and possibly also } \\
\text { singleplayer and multiplayer game title(s) }\end{array}$ & 29 & 10.4 \\
& Missing & 8 & 2.9 \\
\hline Total & & $\mathbf{2 8 0}$ & $\mathbf{1 0 0}$ \\
\hline
\end{tabular}

Table 2. Distribution of learners across groups 1-5 compared with frequency of gameplay (hours per week)*

\begin{tabular}{|c|c|c|c|c|c|c|}
\hline $\begin{array}{l}\text { Frequency } \\
\text { of digital } \\
\text { gameplay }\end{array}$ & $\begin{array}{l}\text { Group 1 } \\
\text { "Non- } \\
\text { gamers" }\end{array}$ & $\begin{array}{l}\text { Group } 2 \\
\text { "No title } \\
\text { given" }\end{array}$ & $\begin{array}{l}\text { Group } 3 \\
\text { "Singleplayer" }\end{array}$ & $\begin{array}{l}\text { Group } 4 \\
\text { "Multiplayer" }\end{array}$ & $\begin{array}{l}\text { Group 5 } \\
\text { "Massively } \\
\text { multiplayer" }\end{array}$ & Total \\
\hline $0 \mathrm{hrs} / \mathrm{w}$ & 108 & 1 & 0 & 1 & 0 & 110 \\
\hline$<3 \mathrm{hrs} / \mathrm{w}$ & 0 & 10 & 19 & 14 & 3 & 46 \\
\hline $3-9 \mathrm{hrs} / \mathrm{w}$ & 0 & 10 & 11 & 23 & 8 & 52 \\
\hline$>9 \mathrm{hrs} / \mathrm{w}$ & 0 & 1 & 1 & 44 & 18 & 64 \\
\hline Total & 108 & 22 & 31 & 82 & 29 & 272 \\
\hline
\end{tabular}

\subsection{Analytic procedure}

To compute significance and effect sizes for tests with numeric variables, oneway analysis of variance (ANOVA) together with classical eta squared $\left(\eta^{2}\right)$ was used. In line with Cohen's (1988) convention for $r^{2}, \eta^{2}=.01$ is a small effect size, $\eta^{2}=.06$ is medium, and $\eta^{2}=.14$ is large (Dörnyei, 2007). Gabriel's posthoc test was used to examine which groups differed from which within the 
general between-groups differences. Due to the uneven distribution of learners across the groups, Gabriel's test was preferred over, for example, S-N-K. To compute significance and effect sizes for tests with nominal variables, Pearson's chi-squared $\left(\chi^{2}\right)$ and Cramér's (1946) V $\left(\varphi_{c}\right)$ were used. In line with Cohen's (1988) convention for $d$ which is also often used for Cramér's $\mathrm{V}, \varphi_{\mathrm{c}}=.2$ is a small effect size, $\varphi_{\mathrm{c}}=.5$ is medium, and $\varphi_{\mathrm{c}}=.8$ is large (Aron, Aron, \& Coups, 2005).

\section{Results}

Internal consistency measures showed that the PLT and VLT were reliable $(r=.778, p=.000$; Cronbach's $\alpha=.777)$. Results for both tests are shown in Table 3. Group 4 scored the highest on the PLT, followed by Group 5, 3, and 1 . Analysis of variance indicated that there was no significant difference of mean scores among the groups $(F(3,155)=1.59, p=.193)$. For the VLT, again Group 4 scored the highest, and the other groups followed as for the PLT. ANOVA indicated that there was a significant difference of mean scores among the four groups for the $\operatorname{VLT}(F(3,147)=3.61, p=.015)$. Gabriel's post-hoc test showed that the score for Group 2 was different from Group $4(p=.005)$, but that the remaining group comparisons were indistinguishable from one another. Finally, effect sizes were small for the PLT, a test of productive vocabulary size $\left(\eta^{2}=.030\right)$, and medium for the VLT, a test of receptive vocabulary size $\left(\eta^{2}=.069\right)$.

Although the scores for the non-gamers (Group 1) are irrelevant for the validation of the SSI Model, they are relevant from the perspective of the relation between digital gameplay and vocabulary acquisition and, therefore, provided in Table 4.

Table 3. PLT and VLT scores for groups $2-5$

\begin{tabular}{|r|c|c|c|c|c|}
\hline & $\begin{array}{c}\text { Group 2 } \\
\text { "No title } \\
\text { given" }\end{array}$ & $\begin{array}{c}\text { Group 3 } \\
\text { "Singleplayer" }\end{array}$ & $\begin{array}{c}\text { Group 4 } \\
\text { "Multiplayer" }\end{array}$ & $\begin{array}{c}\text { Group 5 } \\
\text { "Massively } \\
\text { multiplayer" }\end{array}$ & $\begin{array}{c}\text { Significance } \\
\text { Effect size }\end{array}$ \\
\hline $\begin{array}{r}\text { PLT } \\
(\text { max: } 45)\end{array}$ & & & & & \\
mean & 14.90 & 18.65 & 20.19 & 18.79 & \\
\hline SD & 9.00 & 10.00 & 10.51 & 8.50 & $p=.193$ \\
\hline$n$ & 21 & 31 & 79 & 28 & $\eta^{2}=.030$ \\
\hline VLT & & & & & \\
$($ max: 90$)$ & & & & & \\
\hline mean & 48.86 & 59.42 & 63.64 & 61.96 & \\
SD & 18.67 & 18.50 & 18.50 & 19.86 & $p=.015$ \\
\hline$n$ & 22 & 31 & 75 & 23 & $\eta^{2}=.069$ \\
\hline
\end{tabular}


Table 4. Scores for Group 1 on the vocabulary tests

\begin{tabular}{|r|c|c|}
\hline & $\begin{array}{c}\text { PLT } \\
(\max : 45)\end{array}$ & $\begin{array}{c}\text { VLT } \\
(\max : 90)\end{array}$ \\
\hline mean & 16.26 & 55.99 \\
\hline SD & 9.00 & 17.71 \\
$n$ & 105 & 102 \\
\hline
\end{tabular}

\section{Discussion}

Based on sociocultural theory (Vygotsky, 1978), the SSI Model proposes a classification of commercial off-the-shelf digital games into three categories: singleplayer, multiplayer, and massively multiplayer online games. As argued in Sundqvist (2013), the potential for naturalistic learning (Benson, 2011) of English is hypothesized to be greater the larger the scale of the in-game social interaction. In other words, the larger the scale of social interaction offered by particular games, the higher the chances of encountering co-players of different nationalities, making the need for a shared language (i.e. English) for in-game interactions obvious. Subsequently, the more authentic English interactions there are, the higher the chances for naturalistic language learning to occur. The scale of social interaction is viewed as a continuum, from small scale (singleplayer games) to large scale (MMOs). From the perspective of language learning, the SSI Model suggests that MMOs are more beneficial than multiplayer games which, in turn, are more beneficial than singleplayer games.

The results reveal that it is more common that learners who play games frequently play multiplayer games and/or MMOs. Further, the results provide partial evidence of the validity of the SSI Model in that the learners categorized into Groups 4 and 5 score higher than Groups 3 and 2.

\section{Concluding remarks}

This study provides evidence for partial validation of the SSI Model. It was not possible to verify that learners categorized as playing MMOs (Group 5) score significantly higher than learners categorized as playing multiplayer games (Group 4) but, on the other hand, as hypothesized, learners categorized as playing singleplayer games (Group 3) nevertheless scored lower than both Groups 4 and 5, and the lowest scores were found among learners who failed to provide any game titles (Group 2). Upon completion of the 3-year study, which should include a sample of around 1,000 learners, final validation of the SSI Model can be made. 
Acknowledgements. An early version of the SSI Model has been published as Sundqvist (2013). I would like to thank the Center for Language and Literature in Education, Karlstad University, for funding the last two years of the project.

\section{References}

Apperley, T. H. (2006). Genre and game studies: Toward a critical approach to video game genres. Simulation \& Gaming, 37(1), 6-23. doi:10.1177/1046878105282278

Aron, A., Aron, E. N., \& Coups, E. J. (2005). Statistics for the behavioral and social sciences: A brief course (3rd ed.). London: Prentice Hall International.

Benson, P. (2011). Teaching and researching autonomy (2nd ed.). Harlow: Pearson Education.

Cohen, J. (1988). Statistical power analysis for the behavioral sciences (2nd ed.). New Jersey: Lawrence Erlbaum.

Cramér, H. (1946). Mathematical methods of statistics. Princeton: Princeton University Press.

deHaan, J. (2005). Learning language through video games: A theoretical framework, an evaluation of game genres and questions for future research. In S. P. Schaffer \& M. L. Price (Eds.), Interactive convergence: critical issues in multimedia (pp. 229-239). Oxford: Interdisciplinary Press.

Dickey, M. D. (2006). Game design narrative for learning: Appropriating adventure game design narrative devices and techniques for the design of interactive learning environments. Educational Technology Research \& Development, 54(3), 245-263. doi: 10.1007/s11423006-8806-y

Dörnyei, Z. (2007). Research methods in applied linguistics. Oxford: Oxford University Press.

Greenberg, B. S., Sherry, J., Lachlan, K., Lucas, K., \& Holmstrom, A. (2010). Orientations to video games among gender and age groups. Simulation \& Gaming, 41(2), 238-259. doi: $10.1177 / 1046878108319930$

Harteveld, C., \& Bekebrede, G. (2011). Learning in single- versus multiplayer games: The more the merrier? Simulation \& Gaming, 42(1), 43-63. doi: 10.1177/1046878110378706

Kinzie, M. B., \& Joseph, D. R. D. (2008). Gender differences in game activity preferences of middle school children: implications for educational game design. Educational Technology Research and Development, 56(5/6), 643-663. doi: 10.1007/s11423-007-9076-Z

Laufer, B., \& Nation, P. (1999). A vocabulary-size test of controlled productive ability. Language Testing, 16(1), 33-51. doi: 10.1177/026553229901600103

Nation, P. (2001). Learning vocabulary in another language. Cambridge: Cambridge University Press.

Sundqvist, P. (2009). Extramural English matters: Out-of-school English and its impact on Swedish ninth graders' oral proficiency and vocabulary. $\mathrm{PhD}$, Karlstad University, Karlstad. Sundqvist, P. (2011). A possible path to progress: Out-of-school English language learners in Sweden. In P. Benson \& H. Reinders (Eds.), Beyond the language classroom (pp. 106-118). Basingstoke: Palgrave Macmillan. 
Categorization of Digital Games in English Language Learning Studies: Introducing the SSI Model

Sundqvist, P. (2013). The SSI Model: Categorization of digital games in EFL studies. European Journal of Applied Linguistics and TEFL, 1(3), 89-104.

Vygotsky, L. S. (1978). Mind in society: The development of higher psychological processes. Cole, M., John-Steiner, V., Scribner, S., \& Souberman, E. (Eds.). Cambridge, MA: Harvard University Press. 